\title{
Exploitation of mineral resource and its influence on regional development and urban evolution in Xinjiang, China
}

\author{
DONG Wen", "YANG Yu²
}

1. Xinjiang Institute of Ecology and Geography, CAS, Urumqi 830011, China;

2. Institute of Geographic Sciences and Natural Resources Research, CAS, Beijing 100101, China

\begin{abstract}
The aim of this paper is to analyze the relationship between mineral resources exploitation and economic and urban development in Xinjiang. The article summarizes the mineral resource exploitation development of Xinjiang especially over the last 50 years, and investigates energy industries and their driving forces, directions, and economic impact on the oasis urban system evolution in Xinjiang. Methods like correlation analysis, location quotient and elastic coefficient are employed in the presentation and discussion, and also field reconnaissance surveys, interviews and secondary sources are used. The result shows Xinjiang's economic growth is promoted by the contributions of the increasing mineral resource industry which promotes economic development by accelerating infrastructure construction, developing industry and raising revenue and fixed investment. Mineral exploitation in recent years had profound impacts on urban development as a growth engine. The evolution of urban system has a close relationship with resource exploitation, and statistical results provide strong evidence to support the argument that mineral resource exploitation has promoted the growth of built-up areas and its expansion patterns in Xinjiang, especially regions along the northern slope of the Tianshan Mountains.
\end{abstract}

Keywords: exploitation of mineral resource; oasis city development; Xinjiang

\section{Introduction}

Xinjiang Uygur Autonomous Region (XUAR), locating in the central part of Asia with an area of 1.66 million $\mathrm{km}^{2}$ and being named as "the Western Gateway of China", accounts for one-sixth of China's territory and a quarter of China's border length. Its geographical coordinates range from $73^{\circ} 41^{\prime}-96^{\circ} 18^{\prime} \mathrm{E}$ to $34^{\circ} 22^{\prime}-49^{\circ} 33^{\prime} \mathrm{N}$, bordering Kyrgyzstan, Uzbekistan, Kazakhstan, etc. Xinjiang is strategically important because of its position along the country's western border where China adjoins Central Asia (Piper, 1996). At present, Xinjiang

Received: 2014-04-24 Accepted: 2014-05-20

Foundation: National Natural Science Foundation of China, No.41371141; No.41401132; No.41430636

Author: Dong Wen (1976-), Associate Professor, specialized in economic geography and urban geography.

E-mail: dongwen@ms.xjb.ac.cn

"Corresponding author: Yang Yu (1984-), $\mathrm{PhD}$, specialized in economic geography and energy geography.

E-mail: yangyu@igsnrr.ac.cn 
has a population of over 22.33 million in 2012 among which some 10.64 million people were registered as non-agricultural residents in the household registration system. A total of 49 nationalities, in which Han, Uygur, Kazak, Hui, Mongolian and Khalkhas are the majority, dwell in Xinjiang, the multi-national province. Over $60 \%$ of the nationalities are ethnic minorities and 13 of the nationalities are old settlers. Xinjiang, just as the other provinces in China, underwent the collectivization process in the 1950s and the Cultural Revolution from 1966 to 1976 . The annual net income per rural resident was 166 RMB yuan in 1952 and the total population was only 0.43 million in 1949. Since the implementation of economic reform and the opening-up policy in 1978, Xinjiang received a series of favorable economic and political policies and seized great opportunities for its development. Especially in the last 20 years, Xinjiang has made tremendous progress in its economy and all aspects of social life. Per capita GDP (Gross Domestic Product) of Xinjiang in 2012 was 33,796 yuan, which was 204 times that of 1952 and ranked first among all the non-coastal provinces in China. Urbanization level has been dramatically enhanced in Xinjiang from $12.21 \%$ to $46.60 \%$ during the period 1952-2012. And also a number of cities in Xinjiang have greatly developed. There were only 3 cities in 1952, while there were 22 cities and 11 municipal districts in 2012 (Figure 1). Most of those cities aggregate along the northern slope of Tianshan Mountains, and form a prototype of urban agglomeration which takes Urumqi as the center and Shihezi and Karamay as the subcenters.

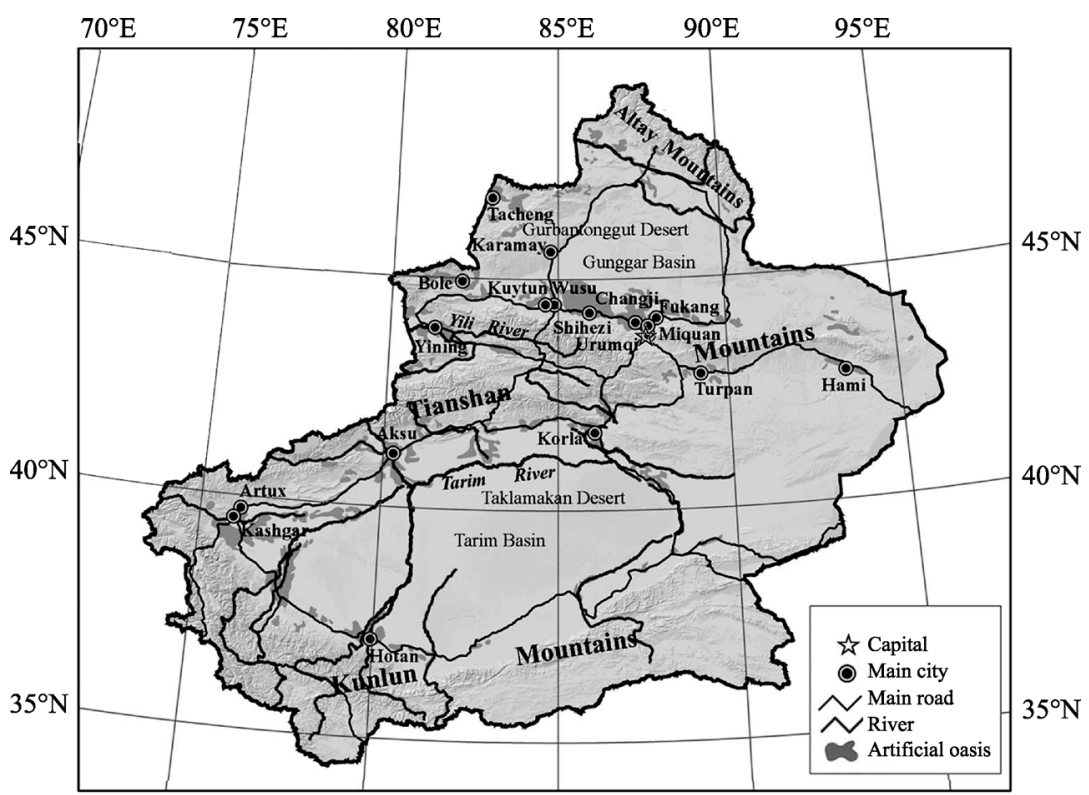

Figure 1 Distribution of major oasis cities in Xinjiang, China (Source: Liu, 2010)

Currently, Xinjiang is viewed as the "Pivot of Asia" and a "new center of gravity" among Europe, Middle East and Central Asia. Xinjiang is not only one of the important windows for China to the outside world but also the pacesetter in the implementation of China's strategy for large-scale development in western China. Regional pattern in Xinjiang is undergoing great vicissitudes nowadays in consequences of rapid economic growth, changeful geopolitical circumstances in relations with the Central Asian countries and ever-increasing demands for energy which are driving resource exploration and expanding the transportation 
network (Zhang et al., 2011; Wang et al., 2011). Due to its vast territory and abundant resources, Xinjiang occupies a highly important strategic position. These facts above suggest that there is something distinctive and special about Xinjiang itself and Xinjiang's role in China's contemporary development.

China's oil demand has been increasing consistently since the implementation of economic reform and opening-up policy in 1978. China's booming economy, with an average annual growth of nearly $10 \%$ in the last three decades, requires massive levels of energy to sustain its growth. Under this situation, Xinjiang is going to be constructed as a significant world supplier of energy especially in the oil and gas sectors according to appropriate government planning, and the region is likely to diminish OPEC's (Organization of Petroleum Exporting Countries) influence on the global oil market over the long term. Moreover, Xinjiang becomes China's largest strategic region of petroleum industry as the government shifts its focus of oil development to western regions. It is also argued that the process of mineral resource exploitation attributes to recent urban developments in Xinjiang. And cities development especially cities' physical constraints and institutional controls is strongly influenced by resource exploitation.

One of the major research topics in urban geography is oasis city development and its dynamics which refers to the spatio-temporal changes in the number of cities as well as scale and distribution ( $\mathrm{Du}$ et al., 2011). Due to limited data and inconspicuous economic achievement of Xinjiang, little research has been published on the relationship between mineral resource exploitation and economic development and urban growth. The paper offers a glimpse into development status of Xinjiang after the foundation of People's Republic of China (PRC), with a focus on mineral resource exploitation and mineral industry development and its impact on recent economic and urban development. And we also assess the future outlook of mineral resource exploitation and its potential impact on urban development of Xinjiang.

\section{Methods}

To examine the change of the geographical structure of mineral resource industry, we constructed geographical concentration indices for each industry to uncover the spatial distribution and provincial specialization. Many indices have been used in the literature, such as the elastic coefficient, location quotient and correlation analysis. We computed all these indices and found that they are strongly correlated.

\subsection{Correlation analysis}

To describe the impact that mineral resource exploitation had on economic and urban development in Xinjiang, we constructed a correlation test index of the gross industrial output value of mineral resource and the gross domestic product, taking the economic index as the independent variable while taking natural, social, economic and other factors as dependent variables. Next, we classified and selected the indices and obtained a relative factor set of economic and urban development:

$$
f=\left\{f_{1}, f_{2}, f_{3}, \ldots \ldots, f_{n}\right\}
$$

where $f_{n}$ is the first selected relative factor of economic and urban development. Then we selected factors that could be quantified as factors of economic and urban development. 
Based on these, we analyzed the main quantifiable factors of economic and urban development. The other main factors could be analyzed qualitatively.

\subsection{Location quotient}

The location quotient $(L Q)$ is a useful tool for comparing area characteristics. Individual location quotient standard deviations play an important role in comparing area characteristics. We used $L Q$ to analyze the national status of the mineral resource industry of Xinjiang:

$$
L Q_{i j}=\frac{E_{i j} / E_{i}}{E_{i} / E}
$$

where $L Q_{i j}$ is the location quotient of $i$ specific industries department of area $j ; E_{i j}$ is the gross industrial output value of $i$ specific industries of area $j ; E_{i}$ and $E_{j}$ are national gross industrial output values of $i$ and $j$ departments, respectively; and $E$ is the national gross industrial output value. The magnitude of the $L Q$ can be interpreted to indicate the specialized level of the mineral resource industry of Xinjiang in the whole country, depending on whether the $L Q$ is greater than, less than, or equal to 1.0 .

\subsection{Elastic coefficient}

For further explanation of the coordination between growth speed of an urban built-up area and non-agricultural population growth rate, the elastic coefficient of urban land use is used to measure the characteristics of urban built-up area growth (Wang et al., 2007). The mathematical expression of elastic coefficient is:

$$
R(i)=A(i) / \operatorname{Pop}(i)
$$

where $R(i)$ is the expanded elastic coefficient of urban area $i ; A(i)$ is the area annual growth rate of urban area $i$; and $\operatorname{Pop}(i)$ is the non-agricultural population growth rate of urban area $i$. Theoretically, the growth rate of an urban area should be less than the non-agricultural population growth rate (Maxim et al., 2002). In other words, the value of the elastic coefficient should be below 1 in ideal conditions.

\subsection{Data sources}

Annual statistical data from Statistical Yearbook of Xinjiang and Annual Report of Xinjiang Industrial Statistics (both published by the State Statistical Bureau) were used to calculate correlation analysis, location quotients, and elastic coefficients and to quantitatively analyze the relative factors of urban expansion. Statistical data were processed by Excel. We expanded the dataset to all the 13 energy resource industries during the period 1995-2012. The temporal trends of mineral resource industries were not systematically investigated for Statistical Yearbook of Xinjiang only includes 13 mineral resource industries by province since 1993. To measure provincial specialization, we exchanged the industry and province data in equation. Field reconnaissance surveys, interviews, and secondary sources were also used in the presentation and discussion.

\section{Results}

\subsection{General status of Xinjiang's mineral resources}

Xinjiang features abundant mineral resources and rich assortments where 138 minerals were 
found so far. Among them, the reserves of 117 minerals were verified and the reserves of 43 minerals ranked the world's top ten. Xinjiang is also now an important oil and petrochemical production base in western China. In particular, Xinjiang has significant coal, gas reserve and an uncertain oil reserve. Xinjiang has an average annual production of 130 billion $\mathrm{m}^{3}$ of natural gas since 2000, becoming one of the largest natural gas producer in China. Reserves of Xinjiang's oil and natural gas were estimated at $2.09 \times 10^{10}$ tons and $1.30 \times 10^{13} \mathrm{~m}^{3}$, accounting for $30 \%$ of the nation's inland crude oil reserves and $34 \%$ of the nation's natural gas reserves respectively. Large oilfields with reserves up to 100 million tons have been discovered in Xinjiang almost every year as exploration continues although there was barely any oil been found here when the People's Republic of China was established in 1949.

Xinjiang became an oil producer largely due to the discovery of the Karamay oil field which is now the oilfield with the largest reserves in China. Reserves of oil and natural gas in the three large basins in Xinjiang (Tarim, Junggar, and Turpan-Hami) were verified at 20.9 billion tons and 10.85 trillion $\mathrm{m}^{3}$, accounting for $25.5 \%$ of the total oil reserves and $27.9 \%$ of the total natural gas reserves onshore in China respectively (Figure 2). Moreover, cooperation with other regions of Central Asia will also be an important way for China to alleviate energy shortages. Xinjiang's coal reserves are concentrated along the northern slope of Tianshan Mountains. Coal reserves in this area were estimated at $2.20 \times 10^{12}$ tons, accounting for $40.5 \%$ of China's total coal reserves, with an annual production of almost 90 million tons. These rich and high-quality resources will play a leading role in the development of energy industry in Xinjiang.
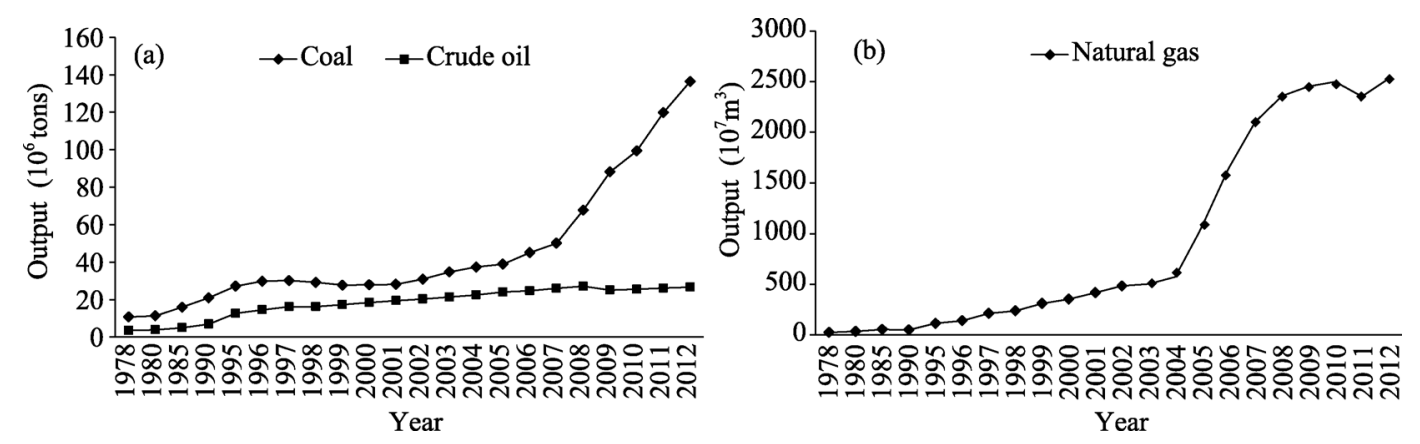

Figure 2 Output of coal, crude oil and natural gas of Xinjiang during 1978 to 2012 (Source: XTY, 1979-2013)

Energy is the most abundant and valuable natural resource in Central Asia includes oil, gas, coal, and renewable (James, 2006). A number of pipelines have already been completed, including the China-Kazakhstan Crude Oil Pipeline First-Phase Project and the Western China Pipeline, which provide critical infrastructure upon which China can exploit its natural resources and bring oil to eastern China (Clifton et al., 1997, 2006). In 2012, Xinjiang ranked fifth among China's oil-producing regions by generating 26.70 million tons of crude oil, and second among gas-producing regions by producing 25.30 billion $\mathrm{m}^{3}$ of natural gas (Figure 2). Driven by local oil and gas development and China's cooperation with West Asian countries in relevant fields, the construction of pipelines in Xinjiang is advancing rapidly. By 2012, Xinjiang had a network of pipelines covering southern, northern and eastern Xinjiang and with a total length exceeding 12,843 km. 


\subsection{Exploitation of mineral resources and regional development}

\subsubsection{Economic growth and structural change in industry}

Xinjiang was an agroeconomy-oriented region with underdeveloped industry and without modern factories and mines before the foundation of PRC. The GDP of Xinjiang was 750.5 billion yuan in 2012, which was 943 times of that in 1952. The annual growth rate of Xinjiang was $12.32 \%$ from 1952 to 2012 . In 1952, the gross value of production of primary industry comprised $64.73 \%$ of the GDP, while the secondary industry and the tertiary industry comprised $22.00 \%$ and $13.27 \%$ respectively of the GDP. In 1965, the ratio of the gross value of production of the primary industry to GDP was $51.57 \%$, while that of the secondary industry increased to $30.25 \%$, and that of the tertiary industry increased to $18.18 \%$ (Figure 3 ). The gross value of production of primary, secondary and tertiary industries accounted for $17.6 \%, 46.4 \%$ and $36 \%$ of the GDP in 2012 respectively. Compared with 1952, the proportion of the gross value of production of the primary industry dropped by $47.13 \%$, while that of the secondary industry and that of tertiary industry rose by $23.40 \%$ and $22.73 \%$ respectively (Figure 3).

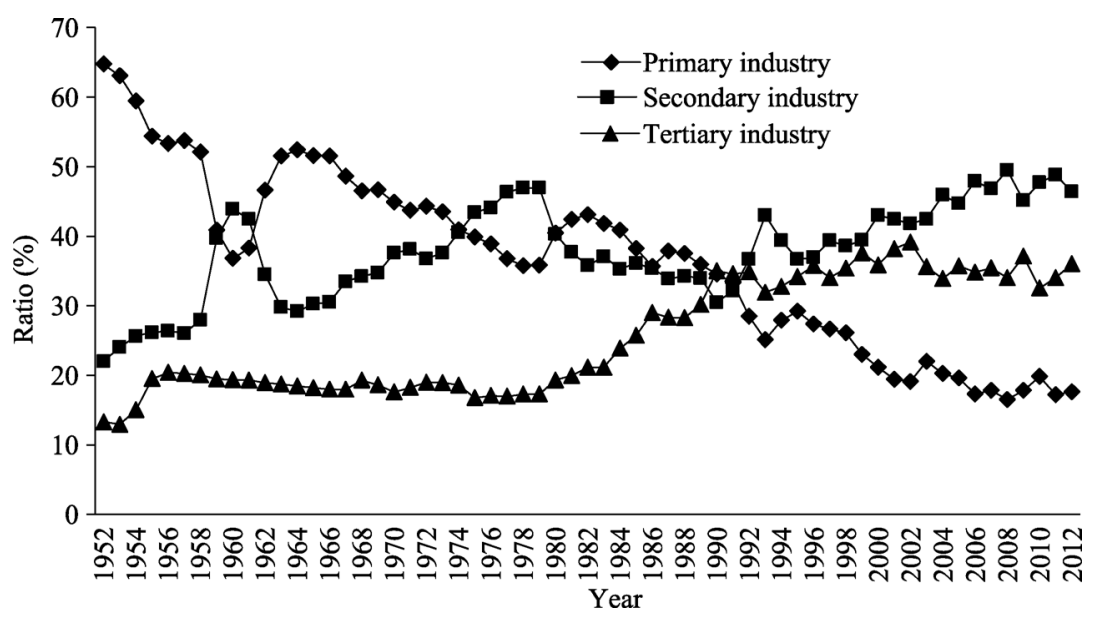

Figure 3 Composition of the GDP in Xinjiang (1952-2012)

In fact, development in this region was on a relatively lower step and was inferior to that in eastern China, and economic and social gaps between this region and eastern China were dramatically widened consequently. As a result, Great Exploration of the West driven by political forces and the desire of exploiting natural resources was carried out in 2000. Investment in generation capacity increased from 74.7 billion yuan to 322.6 billion yuan at an average annual increase of $28 \%$ from 2000 to 2007 . Accompanying with the rapid economic development in Xinjiang, mineral resource exploitation grew faster year by year. Production volume of crude oil, raw coal and natural gas in Xinjiang was 26.71 million tons, 136.47 million tons and 25.3 billion $\mathrm{m}^{3}$ respectively in 2012, which was 7.56 times, 12.65 times and 100.80 times that of 1978 . Both industrial strength and technological level have notably risen in this region.

Correlation degrees between the gross industrial output value of mineral resource and GDP, between per capita GDP and gross industrial output value, and between per capita 
GDP and gross industrial output value of mineral resource were $0.990,0.993$ and 0.986 respectively (Table 1). Increasing of the mineral resource industry promotes the development of infrastructure, revenue, industry and fixed investment, and thus driving economic development and urban expansion. Large investments in the oil and gas industry have led to the construction of foundational facilities for oasis cities and transportation infrastructure. Industrial expansion was the dominant factor in urban expansion for cities such as Karamay, Korla and Hami.

Table 1 Relationship of petroleum exploitation and economic development in Xinjiang

\begin{tabular}{|c|c|c|c|c|c|c|c|}
\hline Index & $\begin{array}{l}\text { Gross industrial } \\
\text { output value of } \\
\text { mineral re- } \\
\text { sources }\end{array}$ & GDP & $\begin{array}{l}\text { Per } \\
\text { capita } \\
\text { GDP }\end{array}$ & $\begin{array}{l}\text { Gross } \\
\text { industrial } \\
\text { output } \\
\text { value }\end{array}$ & $\begin{array}{c}\text { Fixed } \\
\text { invest- } \\
\text { ment }\end{array}$ & $\begin{array}{l}\text { Investment } \\
\text { of capital } \\
\text { construc- } \\
\text { tion }\end{array}$ & $\begin{array}{c}\text { Reve- } \\
\text { nue }\end{array}$ \\
\hline $\begin{array}{l}\text { Gross industrial output } \\
\text { value of mineral } \\
\text { resources }\end{array}$ & 1.000 & & & & & & \\
\hline GDP & 0.990 & 1.000 & & & & & \\
\hline Per capita GDP & 0.993 & 0.999 & 1.000 & & & & \\
\hline $\begin{array}{l}\text { Gross industrial output } \\
\text { value }\end{array}$ & 0.986 & 0.994 & 0.994 & 1.000 & & & \\
\hline Fixed investment & 0.973 & 0.993 & 0.987 & 0.985 & 1.000 & & \\
\hline $\begin{array}{l}\text { Investment of capital } \\
\text { construction }\end{array}$ & 0.960 & 0.984 & 0.978 & 0.977 & 0.996 & 1.000 & \\
\hline Revenue & 0.949 & 0.969 & 0.960 & 0.963 & 0.976 & 0.969 & 1 \\
\hline
\end{tabular}

\subsubsection{Secondary industry development}

After 1949, Xinjiang entered the period of socialist construction and developed with a speed surpassing that of previous periods. It received heavy fixed investment after the foundation of the PRC, which laid the groundwork for economic development and also triggered urban development. There were only 363 industrial enterprises in Xinjiang with an annual output value of 98 million yuan in 1949 while there were 1959 industrial enterprises above designated size with a gross industrial output value of 753.27 billion yuan in 2012. Output value of major industrial production has increased substantially. A large proportion of Xinjiang's secondary industry was light industry such as food processing, textile industry, sewing, leather working, etc. while there were barely any heavy industries like ferrous metal metallurgy, non-ferrous metal metallurgy or petrochemical industry.

Large-scale industrial construction in Xinjiang was carried out from 1952 to 1954 and received investment from the central government mostly. Enterprises like the Bayi Steel Corporation, Shiyue Automobile Repair Plant, Liudaowan Mines, Qiyi Cotton Mill, etc. were established in this period and then gradually became the primary drivers of urbanization and subsequent urban expansion. Xinjiang's industrial structure, dispersing spatially significantly in the 1980s and concentrating in the 1990s, has been constantly adjusted and optimized with the exploitation process of mineral resources. These industries included timber processing, paper making and paper products, printing and copying, chemical materials and products, chemical fibers, rubber products, ferrous metal smelting and pressing, non-ferrous metal smelting and pressing, metal mineral products, and machinery. There was 
a concentration of industry in the five cities (Urumqi, Korla, Shihezi, Hami and Karamay) where more than $59.32 \%$ of value added in these industries was produced.

With booming national demand and government support, domestic investors were hopeful for petroleum industry in this region. The competitiveness of Xinjiang's mineral resource industry ranked first in western China and mining was a pillar industry for economic development in Xinjiang (Lu et al., 2009; Du et al., 2011). The annual production values of exploitation and processing of oil and gas account for more than $40 \%$ of the total industrial production value in Xinjiang in 2012. The process of heavy industrialization accompanies with increasing specialization, and industries like machinery, chemical materials and products, petroleum refining and coking, transportation equipment and ferrous metal smelting and pressing are becoming increasingly important.

Mineral exploitation, with its growing contribution to national income and its potential to act as a growth engine, had profound impacts on the urban spatial development of Xinjiang and made great efforts to improve urban development in recent years, especially on aspects of improving urban infrastructure and strengthening municipal finances. Urban and transportation infrastructure constructions were promoted by heavy investments in petroleum and gas industries. Convenient transportation expanded the radiation range of a city and accelerated the land development and urban expansion, thereby enlarging the scale of a city (Liu, 2012).

\subsubsection{Industrial growth related to mineral exploitation}

In recent years, Xinjiang has been industrialized at an ever-accelerating pace by transforming advantageous resources and fostering large enterprises. Many industrial zones (such as the economic belt along the northern slope of Tianshan Mountains, the Urumqi-Changji Hui Autonomous Prefecture integrated economic zone and the Korla-Kuqa petrochemical belt) emerged and 32 national and regional industrial parks have been built. Thermal power and coal-chemical industries also boomed in Xinjiang. The rapid growth of the energy and chemical industries has not only met local demands for energy and petrochemical products but also spurred services and other relevant sectors, playing an important role in upgrading regional economic structure (Du et al., 2011). The GDP of the mineral resource industry was 602.89 billion yuan in 2012, which was 16 times that of 1995 with an annual growth rate of $20.32 \%$.

We selected 13 mineral resources industrial sectors to analyze the relationship between economic development and the mineral resource industry, as noted in Table 2. In 2012, the number of mineral resource industrial enterprises were 1085 , accounting for $55.39 \%$ of the total industrial enterprises above the designated size in Xinjiang. The gross industrial output value of industrial enterprises above the designated size was 753.27 billion yuan and was $95.52 \%$ of the total value in 2012 . The proportion of annual average number of employees working in mineral resource industrial enterprises was $67.95 \%$ to that of the total industrial enterprises above the designated size. It is apparent that mineral resources industrial enterprises became a significant engine for the economic development in Xinjiang.

We analyzed the status of Xinjiang's specialization level of mineral resource industries in the whole country using the method of LQ through which one can clearly assess the status and function of Xinjiang's mineral resource industry (Table 3). The result shows that the status of the mineral resource industry improved significantly from 1995 to 2010. Dominant 
Table 2 Index of mineral resources industrial of Xinjiang in 2012 (10,000 yuan)

\begin{tabular}{|c|c|c|c|c|c|}
\hline Sector & $\begin{array}{l}\text { Number of } \\
\text { enterprises } \\
\quad \text { (unit) }\end{array}$ & $\begin{array}{l}\text { Gross industrial } \\
\text { output value } \\
\text { (at current } \\
\text { prices) }\end{array}$ & $\begin{array}{c}\text { Annual average } \\
\text { employed } \\
\text { persons } \\
\text { (person) }\end{array}$ & $\begin{array}{l}\text { Total } \\
\text { profit }\end{array}$ & $\begin{array}{l}\text { Total profits } \\
\text { and taxes }\end{array}$ \\
\hline Mining and washing of coal & 115 & 2347353.4 & 59104 & 319905.8 & 619285.2 \\
\hline Extraction of petroleum and natural gas & 5 & 13736414 & 77384 & 5845595.9 & 8352044.9 \\
\hline $\begin{array}{l}\text { Mining and processing of ferrous } \\
\text { metals ores }\end{array}$ & 66 & 1216929.3 & 12316 & 201429.1 & 333341.5 \\
\hline $\begin{array}{l}\text { Mining and processing of nonferrous } \\
\text { metals ores }\end{array}$ & 33 & 626231.1 & 8769 & 222087.3 & 302772.6 \\
\hline Mining and processing of nonmetal ores & 22 & 157574.7 & 3604 & 10016.5 & 28540.9 \\
\hline $\begin{array}{l}\text { Oil processing, coking and nuclear fuel } \\
\text { processing }\end{array}$ & 92 & 16731305 & 46489 & -189190.3 & 1766075.7 \\
\hline $\begin{array}{l}\text { Raw chemical material and chemical } \\
\text { products }\end{array}$ & 131 & 5155131.1 & 58208 & 636413.1 & 848407.5 \\
\hline Manufacture of nonmetal mineral products & 294 & 3187246.6 & 56240 & 177575.6 & 310001.6 \\
\hline Smelting and pressing of ferrous metals & 73 & 7407811.5 & 44009 & 38757.1 & 189149 \\
\hline Smelting and pressing of nonferrous metals & 35 & 2402504.4 & 17862 & 109927.5 & 174932.6 \\
\hline Manufacture of metal products & 63 & 767767.2 & 8314 & 27541.2 & 39785.2 \\
\hline $\begin{array}{l}\text { Electricity and thermal production and } \\
\text { supply }\end{array}$ & 132 & 6192713.3 & 55645 & 428461.8 & 667311 \\
\hline Gas production and supply & 24 & 360904.1 & 3786 & 53648.8 & 65739 \\
\hline
\end{tabular}

Table 3 Quotient of location of mineral resources industrial sections of Xinjiang

\begin{tabular}{lrrr}
\multicolumn{1}{c}{ Industry } & 1995 & 2000 & 2010 \\
\hline Mining and washing of Coal & 1.751 & 1.505 & 2.200 \\
Extraction of petroleum and natural gas & 15.965 & 10.106 & 37.291 \\
Mining and processing of ferrous metals ores & 1.351 & 1.730 & 4.728 \\
Mining and processing of nonferrous metals ores & 0.836 & 0.633 & 3.914 \\
Mining and processing of nonmetal ores & 1.261 & 1.122 & 1.499 \\
Oil processing, coking and nuclear fuel processing & 2.479 & 3.319 & 13.764 \\
Raw chemical material and chemical products & 0.559 & 0.366 & 2.136 \\
Manufacture of nonmetal mineral products & 1.042 & 1.168 & 2.069 \\
Smelting and pressing of ferrous metals & 0.683 & 0.685 & 3.449 \\
Smelting and pressing of nonferrous metals & 1.129 & 0.633 & 0.798 \\
Manufacture of metal products & 0.582 & 0.421 & 0.786 \\
Electricity and thermal production and supply & 0.721 & 1.072 & 2.699 \\
Gas production and supply & 0.398 & 0.511 & 2.021 \\
\hline
\end{tabular}

industries like extraction of petroleum and natural gas and oil processing, coking and nuclear fuel processing, played a guiding and post role in the industrial structure of Xinjiang. Moreover, most LQ was enhanced from 1995 to 2010, especially extraction of petroleum and natural gas and oil processing, coking and nuclear fuel processing. Mining and processing of ferrous metals ores and smelting and pressing of ferrous metals, with larger scale comparing with other industries in Xinjiang, possessed a relatively lower specialization level in the whole country. In particular, the industry and economic advantages of mining and 
washing of coal still need to be strengthened.

The contribution of mineral resource industries to economic development was analyzed by the proportion variation of the industrial enterprises above the designated size to industrial enterprises in Xinjiang. The analysis shows that the economic contribution of the mineral resource industries varied in recent years, but its contribution level remained above $40 \%$ from 1995 to 2010. The contribution level declined slightly before 2000 because of global price fall of energy from 1995 to 2000 . However, the contribution level ascended after 2000 since global rebound in prices of energy and for the efforts to strengthen the development of mineral resources. The contribution level increased to $83.93 \%$ in 2010 shows that basic driving force of economic development of Xinjiang is mineral resource exploitation and mineral resource industrial development, especially in recent years.

\subsection{Oasis city development under the influence of mineral resource exploitation}

The officially designated cities in China consist of three ranks: (1) national municipalities directly under the administration of the Central Government, such as Beijing, Shanghai and Tianjin; (2) provincial cities (often called district-level cities) under the administration of provincial governments, and (3) county-level cities under the administration of provincial city governments. Moreover, in the Chinese definitions of administrative and statistical geography, a municipality or provincial city encompasses a relatively large area, comprising of the locus of the city and suburban districts, counties and county-level cities being administered by the city. Xinjiang has jurisdiction over two prefecture-level cities (Urumqi and Karamay), 22 county-level cities (including Shihezi, Turpan, Hami, Changji, Fukang, Bole, Alashankou, Yining, Kuytun, Tacheng, Usu, Korla, Altay, Aksu, Artux, Kashgar, Hotan, Aral, Tumxuk, Wujiaqu, Beitun, Tiemenguan) and 62 counties. These cities above are located in the centre of oases, near rivers or along important transportation routes in Xinjiang (Figure 1). Development in Xinjiang is restricted by many crucial factors, especially shortage of land resources and lack of water resources for the rough natural conditions and relatively weak economic foundation (Jia et al., 2004).

\subsubsection{Generation and distribution of oasis cities}

Mineral distribution has had a great impact upon the distribution of cities in Xinjiang. The effect of mineral resource exploitation on a city can be displayed through three ways: (1) establishing of special mineral cities, such as Karamay and Dushanzi districts; (2) propelling expansion of built-up areas in cities through mineral exploitation, such as Korla and Hami; and (3) developing local economy in cities through mineral exploitation. It can be found that for most cities, the basic motive force of economic development in recent years is mineral resource exploitation and the rapid development of related industries (Table 4).

For instance, Karamay and Dushanzi districts, appearing as a result of petroleum exploration in the western Juggar Basin, not only changed the single function of oasis agricultural cities in Xinjiang but also marked the point where such cities deviated from natural oases for the first time, leading to the development of a network trend in the spatial distribution of cities. Karamay was once a small, indistinct and remote residential town in the vast Gobi Desert until the Karamay oilfield was discovered in 1955. Karamay was designed as a city in the mid-1960s to exploit its rich resources of crude oil. Its crude oil production was 11.03 million tons, accounting for $41.30 \%$ of Xinjiang's crude oil production in 2012 . Both its ur- 
banization level and per capita GDP have been the highest in Xinjiang since 1980 when more than $90 \%$ of GDP in Karamay is generated by industries engaging in crude oil production. Currently, Karamay has evolved into a central city on the northern slope of the Tianshan Mountains.

Table 4 The growth impetus of cities reordered in the top 10 of Xinjiang by GDP (2012)

\begin{tabular}{cccccc}
\hline Rack & City & $\begin{array}{c}1990 \\
\text { (million yuan) }\end{array}$ & $\begin{array}{c}2012 \\
\text { (million yuan) }\end{array}$ & $\begin{array}{c}\text { Annual } \\
\text { growth rate } \\
(\%)\end{array}$ & Main growth impetus \\
\hline 1 & Urumqi City & 43.45 & 200173.9 & 49.43 & $\begin{array}{c}\text { Petroleum, petrifaction } \\
\text { Tertiary industry }\end{array}$ \\
2 & Karamay City & 92.57 & 81070.54 & 38.07 & Petroleum, petrifaction \\
3 & Korla City & 29.76 & 59141.47 & 43.57 & $\begin{array}{c}\text { Petroleum, petrifaction } \\
\text { Secondary and tertiary } \\
\text { industries }\end{array}$ \\
4 & Changji City & 23.7 & 26036.09 & 39.57 & $\begin{array}{c}\text { Petroleum, petrifaction } \\
5\end{array}$ \\
6 & Hami City & 659.63 & 20943.76 & 17.90 & $\begin{array}{c}\text { Secondary industry } \\
7\end{array}$ \\
\hline 8 & Shihezi City & 29.01 & 20819.34 & 36.77 & Primary industry \\
9 & Aksu City & 901.57 & 16253.36 & 14.76 & Primary industry \\
10 & Shan City & 500 & 15345.88 & 17.71 & Petroleum, petrifaction \\
\hline
\end{tabular}

The industrial expansion of Korla illustrates another way through which mineral resource exploitation affects a city. The Tarim oilfield, with its site outside Korla, contains China's largest concentration of oil and gas fields. The prosperity and change in Korla were fully driven by the petroleum industry. In addition, Korla has become one of the three major nonferrous metal producing cities in China and is the largest center of platinum metal refining. Built-up area of Korla expanded accompanying with the mineral resource exploitation.

However, cities like Karamay and Korla still lag behind their counterparts in eastern China on account of their remote location, water scarcity and harsh environment although they were preferentially supported in recent decades for their abundant raw mining resources and social policies of balanced regional development, ethnic unity and national defense.

\subsubsection{Urban system evolution of oasis cities}

Urban systems can be viewed as a whole in Xinjiang, or there can be core and peripheral regions, each with their own system of cities. Cities in Xinjiang are largely located in the arid and semiarid regions of western China, mostly along mountain bases and river banks. Most cities and towns located in Xinjiang also scattered on the diluvial fans and alluvial plains irrigated by the melting mountain glaciers (Jia et al., 2004). Major oasis city centers are located at the junctions of this east-west transportation artery and the south-north river systems (Yang et al., 2010a). Small cities and towns have developed along these transportation routes and rivers. Urban growth has taken a unique path deviating from what is commonly observed in coastal China.

The evolution of the urban system in the semi-arid and arid regions of western China has a close relationship with resource exploitation. Zhang (2002) divided the evolutionary process of oasis urban systems into four phases (Figure 4). In the first phase, there was no influ- 


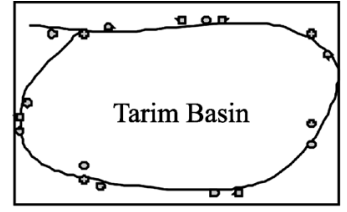

First stage

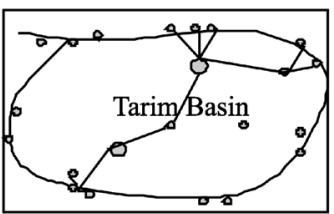

Third stage

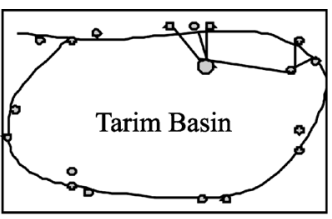

Second stage

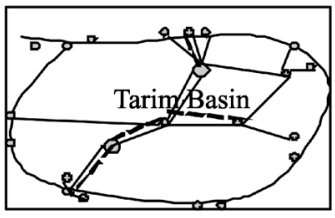

Fourth stage
Figure 4 Evolution of oasis urban system (Zhang, 2002) ence of oil exploration on the urban system evolution, and the oasis city was small and located at the edge of the basin and connected by single lines. During the second phase, towns with water and resources advantages became larger, but the population and city development increased slowly. Petroleum and gas resources were exploited, and new oil towns that deviated from the oasis area were founded. In the third phase, a few larger oil fields were developed in the interior area of the basin; and a few oasis towns with better locations, along with the original petrochemical towns, developed rapidly because of the impetus of the petrochemical industry. During the fourth phase, with the exploitation of additional oil fields in the interior area of the basin, several petrochemical industrial towns developed rapidly, the scale of which was much larger than that of traditional towns (Zhang, 2002).

Through mineral resource exploitation, many special mineral cities were established such as Karamay, Dushanzi, Sandaohaizi, Koktokay, Salt Lake, and Mangya. And the enhancement of urban hierarchy also had driven the development of local economies, such as Shanshan, Korla, Hami and eastern Zhundong base. Industrial development of the cities depended heavily on natural resources, which relied mainly on distributions of mineral resources. For instance, Hami is located at the northwest edge of an alluvial fan and has evolved into a regional industrial site. This has led to the development of a smelting plant at the ore site to lower transportation costs by reducing the volume of the raw iron. Hami was recently designated as a city based on its industrial development, which was due to the nearby oil field. The built-up areas of the city expanded rapidly with industrial development. Recently, the central government of Xinjiang decided to raise the city's grade, which resulted in a change in the hierarchy of cities in Xinjiang.

\subsubsection{Non-agricultural population growth and urbanization level transition}

The relationship between urbanization level and mineral resource exploitation was greatly coupled since 2000 and was effectively and rapidly improved after 2000. Much of the accelerated urbanization has taken place in economically advanced regions along the northern slope of the Tianshan Mountains, particularly in places with the strongest influence of mineral resource exploitation. The 2011 census in Xinjiang clearly identified a pattern of accelerated urbanization. The proportion of non-agricultural population in Xinjiang rose from $12.21 \%$ in 1949 to $46.60 \%$ in 2012 . The non-agricultural population had increased by 10.41 million, up by $34.39 \%$.

The urbanization level was very low in the 1950s and took the first jump in the end of the 1950 s and the beginning of the 1960s as a consequence of the so-called Great Leap Forward movement. Afterward, the urbanization level flattened because of economic rehabilitation. The economic reforms beginning in the 1980s have brought another period of rapid urban development. The cities' and towns' scales in Xinjiang are so small that their urban radiation and attraction ranges are small, and consequently, these cities are unable to attract adequate 
resources and interest for healthy urban development.

\subsubsection{Urban land expansion of oasis cities}

Urban expansion as a dynamic process of land use change is a complicated social and economic phenomenon (Chen et al., 2009; Wang et al., 2007). It may be linked with details related to topography, transportation, land use, social structure, and economic type, but it is generally related to demography and economy in a city (Liu et al., 2010; Yang et al., 2010b). Statistical results provide strong evidence to support the argument that mineral resource exploitation has promoted the expansion of built-up areas in Xinjiang.

Mineral resource-based cities can spend more on urban construction and expand more rapidly overall than undeveloped cities. Although oases comprise less than $10 \%$ of the total area of the region, over $90 \%$ of the population and over $95 \%$ of social wealth are concentrated within the oases (Han 2001). The expansion rate of urban land use has accelerated over the past decade. Rapidly expanding cities are concentrated in the area from Hami to Karamay. It is generally understood that growth in the mineral resource industry results in greater urban expansion - more arable land is encroached upon. The development of mineral exploitation has promoted expansion of several cities: Changji focused on development of peri-urban agriculture, Shihezi developed ecological agriculture and agricultural industrialization, and cities in southern Xinjiang emphasized farming and products of grain and cotton agriculture. Industrial expansion and migration were the dominant factors in urban expansion for Karamay, Yining, Usu, etc. Urban growth may take various spatial forms; however, in most cases it occurs at the edges of an oasis city. By calculating the elastic coefficient, we obtained the correlation relationship between urban expansion and mineral resource exploitation for oasis cities in Xinjiang. The elastic coefficient of most cities along the northern slope of the Tianshan Mountains was above 3.21, while elastic coefficients of the cities located in south Xinjiang were below the reasonable value of 1.01, which implied slower urban expansion compared with the mineral resource industrial growth.

Urumqi, the capital city and the political, economic, cultural, educational, scientific and technological center of XUAR, has become a door connecting China with Central and Western Asia as well as Europe. Urumqi is of vital importance as both a gateway to these resources and a corridor through which they can be imported. To accommodate the rapid economic development and population growth and to mitigate disorganized medium-sized city growth, the Urumqi municipal government limited further growth of the old city and encouraged development of the other districts. Several new industrial and economic development regions were built, and the road system of the urban development axes was improved. Urumqi, the agglomeration point in the Urumqi-Changji Economic Area, has a prosperous economy, strong attractions, and a powerful negotiating ability for material and energy with outside areas. As the center city of Xinjiang, the built-up area has increased by one-third in the past 20 years. The growth of resources exploitation led to an absolute need for developable land in Urumqi, causing an increase in the true urban area, as determined by industrial development (Figure 5). Urumqi's productivity growth in the secondary sector and its high per capita GDP reflect the predominance of the energy sector as a key driver of the industrial output in Xinjiang. Mineral resources industrial development contributed to the expansion and spatial evolution of the city. The scale, speed, and spatial layout of industrial development coincided with the general urban expansion of Urumqi. Concretely, mineral resources 
industries occurred in patched throughout the city while general urban expansion occurred axially, along major roads, and concentrically from the city center. And now spatial distribution of mineral resources industries became more diffuse, similar development in neighboring cities remained concentrated. Urban expansion of Urumqi is predominantly to the suburbs and neighboring cities, transformation of industry also chose the nearest city.

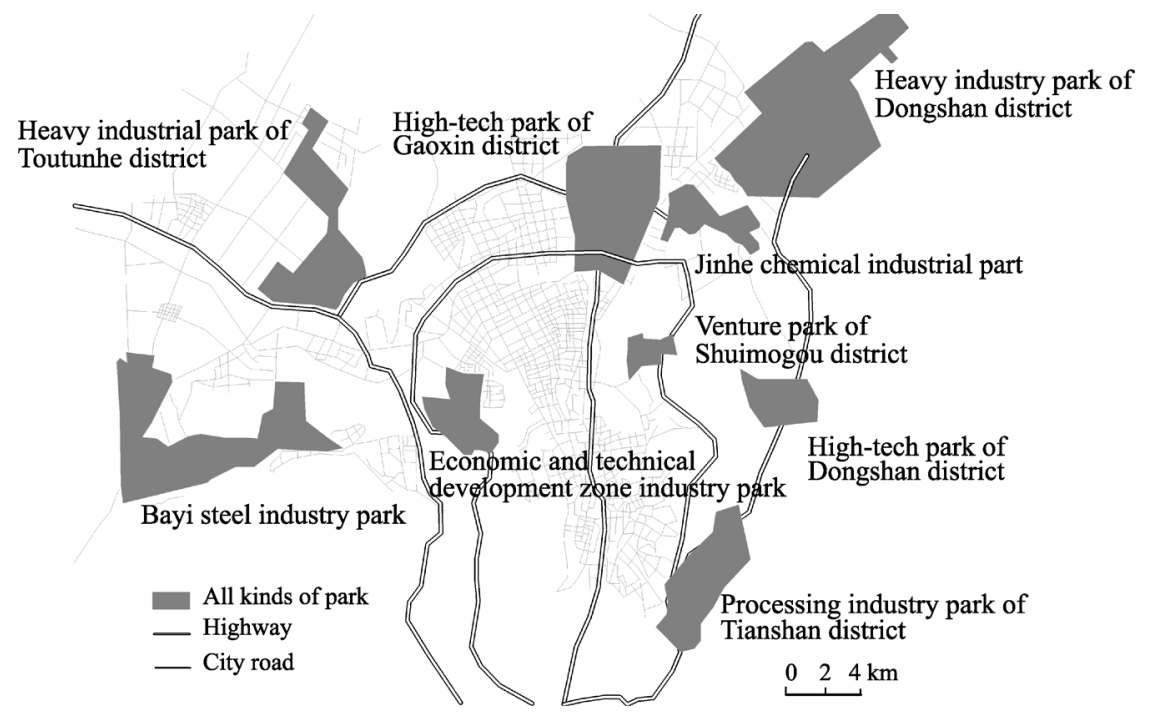

Figure 5 Distribution of main industrial estate in Urumqi

Mineral resources industries are also becoming the important factors for change in the urban expansion pattern of Xinjiang (Li et al., 2010). According to statistics, the headquarters of Tarim Petroleum paid $42 \%$ of the total investment for various types of services, such as engineering projects, domestic purchases, and taxes. Department of petroleum helped the local government build a sewage factory, agricultural product market, water and electricity infrastructure, and most notably, large-scale road construction, such as the 552-km long desert highway. These improvements completely changed the characteristics of the traditional oasis spatial structure, which was generally closed and poorly connected. The construction of a highway across the basin increased traffic and communication between towns. A few oasis towns with better locations, along with the original petrochemical towns, developed rapidly because of the impetus of the petrochemical industry, the scale of which was much larger than that of traditional towns. Their development is characterized by multi-networked communication and transportation. The spatial structure of the urban system has now entered a mature period.

\section{Discussion}

This study has advanced the knowledge of mineral resource exploitation and urban development in Xinjiang. Industries that consume fossil fuels tend to drive industrial development and have a significant impact on the spatial character of the cities where they are located in Xinjiang. Especially, industries that consume fossil fuels also have obvious impetus of the development of the city which is at its peak period. However, the extent, process, and determinants of the spatial distribution of Xinjiang's industries and urban development remain 
under-studied. Future studies should investigate the locational patterns of industries on finer spatial scales. Additionally, further efforts should be made to examine how geographically concentrated the disaggregated industries are and what factors are affecting their geographical patterns. Further research on the characteristics of oasis urban expansion, morphology and the relative factors of change could help in urban design and would be valuable for sustainable urban development in arid regions.

Xinjiang has become the focus of interest by the government and petroleum enterprises. The demand to accelerate exploration and production is quite urgent. Xinjiang should take advantage of its natural resources to build itself into an energy development center. At present, there are several signals that the capital flow direction and the trends of high levels in the energy field indicate that Xinjiang is gradually transforming from a "Backup" into the "Main Force" in the energy industry in China. Xinjiang will become an important strategic oil and gas base in the coming years that can solve the problems of domestic oil and gas shortages.

In the immediate future, oil and gas companies worldwide will continue to encounter an evolving industry in Central Asia, facing with complex issues such as increased competition for capital, environmental constraints, shifting centers of exploration, development and processing, and political change (Jiang et al., 2007; Yang et al., 2010b). In Xinjiang, despite earlier predictions of massive oil resources in the Tarim Basin, new evidence suggests that actual reserves are more modest and more costly to exploit. Although present and scheduled oil production exceeds current and planned oil consumption in this region, it will result in an oil deficit in Xinjiang itself since national policies require the province to transport half of its crude oil to other provinces in China.

\section{Conclusions and policy implications}

We have computed all of the above indices and found that the growth of the mineral resources industries is strongly correlated with economic and urban development. We found significant urban system variations in the relationship and trend of geographical concentration. We also found strong evidence to support the argument that mineral exploitation has an impact on industrial specialization. The intensities of urban development and mineral exploitation have had positive effects on the concentration of economic and construction land use, implying that Xinjiang's industries have followed the less immobile resources to capitalize on the comparative advantage embedded in natural resource endowments.

Now, Xinjiang is in the best period of development, with rapid expansion of its economy and remarkable improvements in living standards. Acceleration of industrialization and urbanization are inevitable for Xinjiang to improve its economic power. Recently, the government of Xinjiang has recognized its need and specified the region's direction and strategic position, that is, be a western international transportation center, a western international trade center, a western energy and equipment manufacturing industrial center, and an energy conservation and energy products-processing center. Undoubtedly, the implementation of these policies has been favorable for energy exploration and exploitation in Xinjiang. Additionally, the key point we would like to point out is, due to the particular characteristics of China's mineral resources management and exploration, how to take advantage of the 
large-scale development of mineral resources exploration. The exploration should not only promote the development of secondary industry, but also upgrade the industrial chain and improve the local economy by means of driving more comprehensive industrial development. Only in this way, development fruit of mineral exploration is not merely the numeral increase of GDP and value of industrial output but can be really shared with the local residents. The current priority of key emphasis in work is to establish an interest coordination mechanism which can handle the relationship among the central government, local government, large exploration enterprises and market as soon as possible.

\section{References}

Chen M X, Lu D D, Zhang H, 2009. Comprehensive evaluation and the driving factors of China's urbanization. Acta Geographica Sinica, 64(4): 387-398. (in Chinese)

Clifton P, Philipp S, 2006. Structural change and regional disparities in Xinjiang, China. Eurasian Geography and Economics, 47(3): 329-352.

Clifton W Pannell, Laurence M, 1997. Urban transition and interstate relations in a dynamic Post-Soviet borderland: The Xinjiang Uygur Autonomous Region of China. Post-Soviet Geography and Economics, 38(4): 206-229.

Du H R, Li X M, Wang C J, 2011. Study on development and regional effects of the energy and mineral resources sectors in Xinjiang. Arid Zone Research, 28(2): 363-369. (in Chinese)

Han D L, 2001. Artificial Oasis in Xinjiang. Beijing: China Environmental Sciences Press. (in Chinese)

James P Dorian, 2006. Central Asia: A major emerging energy player in the 21st century. Energy Policy, 34: $544-555$.

Jia B Q, Zhang Z Q, Ci L J et al., 2004. Oasis land-use dynamics and its influence on the oasis environment in Xinjiang, China. Journal of Arid Environment, 56: 11-26.

Jiang W, Gao W D, Zhang L, 2007. Integrate assessment of energy exploitation in western China. Resources Science, 29(1): 9-15. (in Chinese)

Li X M, Zhang X L, Du H R et al., 2010. An analysis of dynamic econometric on the impact of mineral resource exploitation on the region development: Take Xinjiang as an example. Journal of Natural Resources, 25(11): 1823-1832. (in Chinese)

Liu H B, 2012. Study on grey relation between infrastructure and oasis urban comprehensive size of Xinjiang. Economic Geography, 32(4): 77-89. (in Chinese)

Liu Y X, Zhang X L, Lei J et al., 2010. Urban expansion of oasis cities between 1990 and 2007 in Xinjiang, China. International Journal of Sustainable Development \& World Ecology, 17(3): 253-262.

Lu S J, Zhang X L, Lei J, 2009. Spatial-temporal differentiation of the systemic harmonious degree between cities and industry along the railway lines in Xinjiang. Acta Geographica Sinica, 64(8): 911-923. (in Chinese)

Maxim S, Naftaly G, 2002. Land-use and population density changes in Israel 1950 to 1990: Analysis of regional and local trends. Land Use Policy, 19: 123-133.

Piper R G, 1996. Beyond the Great Wall. Stanford, California, USA: Stanford University Press.

Wang C W, Pu C L, 2011. Benefit-share mechanism on the process of energy mineral resources exploitation in Xinjiang. Economic Geography, 31(7): 1152-1156. (in Chinese)

Wang Q, Zhang Z X, Yi L, 2007. Research on urban expansion in Nanjing, China using RS and GIS. Resources and Environment in the Yangtze Basin, 16(5): 554-559. (in Chinese)

Yang Y, Ma T Y, Zhang X L et al., 2010a. Spatial integration of oasis city group around the western margins of the Tarim Basin. Journal of Arid Land, 2(3): 214-221.

Yang Y, Zhang X L, Lei J et al., 2010b. Sustainable regional development based on resources exploitation and utilization. Scientia Geographica Sinica, 30(3): 363-369. (in Chinese)

Zhang X H, Gu S Z, Wang X J, 2011. Regional effects of mineral resources exploitation and impacts on stakeholders in Xinjiang. Resources Science, 33(3): 441-450. (in Chinese)

Zhang X L, 2002. Influence of desert mineral resource exploitation on the spatial structure of the urban system in Xinjiang. Science in China (Series D), 45(Suppl.): 180-184. 